\begin{tabular}{|c|c|c|}
\hline 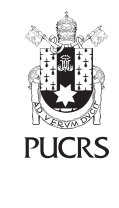 & $\begin{array}{l}\text { ESCOLA DE } \\
\text { HUMANIDADES }\end{array}$ & $\begin{array}{l}\text { Revista de Filosofia da PUCRS } \\
\text { Veritas, Porto Alegre, v. } 65 \text {, n. 1, p. 1-17, jan.-mar. } 2020 \\
\text { e-ISSN: 1984-6746 | ISSN-L: 0042-3955 }\end{array}$ \\
\hline dêt $h$ ttp & $\mathrm{gg} / 10.15448 / 1984-6746.2020 .1 .36892$ & \\
\hline
\end{tabular}

VARIA

\title{
Utopias Autárquicas - Autonomia irracional da natureza
}

\author{
Autarkic utopias - The irrational autonomy of nature \\ Utopias autárquicas - Autonomía irracional de la naturaleza
}

\author{
Nelson Costa Fossatti ${ }^{1}$ \\ orcid.org/0000-0001-5895-7604 \\ nfossatti@terra.com.br
}

Recebido em: 20 jan. 2020. Aprovado em: 31 jan. 2020 Publicado em: 12 mai. 2020

\section{(c) (1)}

Artigo está licenciado sob forma de uma licença Creative Commons Atribuição 4.0 Internacional.
Resumo: Este artigo pensa as contingências decorrentes das máquinas autônomas da natureza no universo das utopias concretas. Pensa como artefatos podem ganhar autonomia diante da irracionalidade da matéria? É sabido que as máquinas utópicas podem exteriorizar um poder desconhecido do ser humano e alcançar uma condição autárquica diante do descaso de seu criador. Ernst Bloch situa tais utopias no $3 .^{\circ}$ nivel da categoria, um ainda-não-ser, que na sua ontologia responde a "possibilidade conforme estrutura do objeto real". Contingências e imprevisibilidades advindas neste nível determinam a dimensão autônoma das utopias técnicas. A evolução do processo dinâmico e complexo da matéria - natura naturata (potencialidade-possibilidade passiva) que se acha velada, uma vez desperta assume a dimensão de natura naturans (potência-possibilidade-ativa). A natureza que produz natureza revela que a ação do homem sobre a matéria transforma sonhos utópicos acordados em pesadelos distópicos acordados, determinando uma diversidade de utopias autárquicas que ameaçam a humanidade. Esse contexto recepciona o alvorecer de novas utopias técnicas. que aponta uma não conformidade na geração das máquinas autárquicas bem como, a ausência de uma linguagem ética entre homo utopicus e natura naturans. Palavras-chave: Homo Utopicus, Autonomia da natureza, Utopias autárquicas, Ética Irracional.

Abstract: This paper reflects on the contingencies resulting from the autonomous machines of nature in the universe of concrete utopias. It considers the way artefacts achieve autonomy before the irrationality of matter. It is known that utopian machines can express a power unknown to the human being and reach an autarkic condition in face of their creator's negligence. Ernst Bloch ascribes these utopias to a third level category", a not-yet-being that, in his ontology. corresponds to the "possibility structure of the real object". Contingence and unpredictability occurring at this level determine the autonomous dimension of technical utopias. The evolution of the dynamic and complex process of matter - natura naturata (potentiality - passive possibility). The nature thet produces nature reveals that man's action over matter transforms utopian daydreams into dystopian daydreams, establishing a range of utopian autarkies that threaten humanity. This context welcomes the dawn of new technical utopias, indicating a non-conformity in the generation of autarkic machines as well as the absence of an ethical language between the homo utopicus and the natura naturans.

Keywords: Autarkic Utopias, Homo Utopicus, Autonomy of Nature, Ethical Irrational.

Resumen: Este artículo piensa las contingencias derivadas de las máquinas autónomas de la naturaleza en el universo de las utopías concretas. ¿Piensa cómo los artefactos pueden ganar autonomía ante la irracionalidad de la materia? Es sabido que las máquinas utópicas pueden exteriorizar un poder desconocido del ser humano y alcanzar una condición autárquica ante el desprecio de su creador. Ernst Bloch sitúa tales utopias en el $3^{\circ}$ nivel de la categoria, un todavía-no-ser. que en su ontología responde la "posibilidad conforme estructura del objeto real". Contingencias e Imprevisibilidades que surgen en este nivel determinan la dimensión autónoma de las utopias técnicas. La evolución del proceso dinámico y complejo de la materia - natura naturata (potencialidad-posibilidad pasiva) que se encuentra velada, una vez despierta asume la dimensión de natura naturans 
(potencia-posibilidad-activa). La naturaleza que produce naturaleza, revela que la acción del hombre sobre la materia transforma sueños utópicos despiertos en pesadillas distópicas despiertas, determinando una diversidad de utopias autárquicas que amenazan a la humanidad. Este contexto recibe en los albores de nuevas utopías técnicas, que señala una no conformidad en la generación de las máquinas autárquicas, así como, la ausencia de un lenguaje ético entre homo utopicus y natura naturans.

Palabras clave: Homo Utopicus, Autonomía de la Naturaleza, Utopias, Ética Irracional.

"Princípio do bem comum: Uma superinteligência deverá ser desenvolvida apenas para benefício de toda a humanidade e a serviço de ideais éticos amplamente compartilhados por todos." Nick Bostrom

\section{Utopias - O pesadelo de sonhos acordados}

A natureza embora tenha disponibilizado condições para desvendar e instrumentalizar seus segredos, nem sempre foi receptiva ao homo utopicus, entretanto sempre permitiu que os sonhos acordados fossem mediados pela linguagem técnica e se objetivassem determinando novas utopias técnicas. O termo "utopia" tem um significado etimológico denota dupla interpretação, dependendo da formação da palavra, ouk + topos que pode ser vertido para um "não lugar", dando a ideia de irreal, da itha de fantasia, um lugar inimaginável de um conto de fadas ou, então reconhecida como uma distopia, mau lugar, um lugar do qual se deve fugir, uma utopia negativa. Outra forma de ser deduz- se da junção eu+topos", vertida como "um bom lugar", lugar feliz; ou seja, aqui se percebe a presença de um telos acolhedor, de um ponto de chegada esperado. As utopias autárquicas tem como referência maior, a obra magistral de Ernst IBloch, Espírito Esperança, lque oferece uma visão ontológica da filosofia como ciência primeira. Pensa e Itraduz se revelando a caminhada do ser humano no aspecto transcendental e cultural em seu tempo. As utopias desempenham um papel relevante no processo que alimenta o imaginário dos seres humanos, entre mais representativas estão aquelas que se voltaram para os aspectos sociais e foram [denominadas de "utopias socialistas". Dentre as utopias seminais pode-se destacar a Epopéia de Gigalmesh, as utopias de Platão citado em Crátilo e na República, a mais conhecida Utopia de Thomas Morus, narrativa de uma utopia social através de uma ilha feliz e sonhada pelos seres humanos, inspirado na doutrina hedonista de Epicuro². Essas narrativas são classificadas de diferentes formas tanto para Bloch, Líbano e Petitfils ${ }^{3}$, classificam as utopias sob diferentes aspectos. Líbano ${ }^{4}$ entende as utopias como um fenômeno resultante das relações humanas, um lugar de felicidade dito gratificante. Portanto, deveria existir em algum lugar e, por isso torna-se um modelo a ser desejado considerado o espaço onde o homem alcança realização de suas satisfações. O filósofo humanista, quando questionado sobre onde andam as utopias na modernidade, responde que as utopias não estão nem no endeusamento do progresso em e por si mesmo, nem numa. Visão. apocalíptica do avanço, pois ela aponta na direção da construção de uma sociedade e de relações mais humanas. ${ }^{5}$ Libânio entende as utopias como instrumento do possivel, onde está o locus das realizações e das satisfações, o lugar da felicidade. O filósofo propõe uma tipologia classificando as topias quanto à efetividade, à origem, à forma literária, à localização histórica, à relação passadopresente, à classe ou camada social, ao aspecto da realidade, à relação com a luta, ao lugar do ideal, ao caráter político. Com destaque para utopias escapistas ou alienantes (utopias heroicas e políticas). Diferentemente, Petitfils classifica sua tipologia em três categorias: as fábulas com um enfoque literário romanesco, as utopias críticas

SCHWARTZ. Sandra. A recepção da ética epicurista na utopia de Thomas Morus. Trad. Julia Brandão. Hildesheim: Georg Olms Verlag, 2003. p. 245-295. Thomas Morus deve a Epicuro a visão sonhadora e feliz da ilha da utopia. A doutrina de Epicuro foi condenada pela Igreja e quando Dante escreveu a Divina Comédia, no Canto X do Inferno, lá estava Epicuro. Cf. ALIGHIERI, Dante. A divina comédia. São Paulo: Abril Cultural, 1981. p. 54

3 PETITFILS. Jean-Christian. Os socialismos utópicos. São Paulo: Círculo do Livro, 1977. p. 10-11.

4 LIBÂNIO. Utopia e esperança cristã. São Paulo: Loyola, 1989. p. 16.

5 Ibid., p. 106. 
ou moral, e as utopias sociais que encerram um verdadeiro projeto político (Metamorfoses de Ovídio; Geórgicas de Virgílio; A república de Platão; A cidade do sol de Campanella; Utopia de Thomas Morus). O sistema industrial de SaintSimon, Os Falanstérios de Fourier, Uma nova visão da sociedade de Owen, são utopias sociais que alimentaram e alimentam o pensamento e o imaginário socialista Outra classificação que atende a um sentido de cunho mais filosófico e mais abrangente é dada por Bloch, em sua obra Principio Esperança, classificando-as em: utopias geográficas, médicas, arquitetônicas e técnicas. ${ }^{6}$.

Sobre a dimensão utopica, Libânio, Petitfils, e Bloch têm uma concepção em comum, ambos pensam a utopia na modernidade. Entre eles há uma visão sistêmica do mundo utópico, ambos sugerem conciliar a unidade originária7. Uma vez que as dimensões mediadoras das narrativas utópicas não deram conta de resgatar o construto homem-natureza.

Neste sentido o sonhar acordado para Bloch, significa pensar niveis de possibilidade em que a geração de utopias deve estar ao lado de seu criador, o homem não deve abusar de seus delírios criativos, tão pouco despertar a natureza para gerar ambientes convulsívos. Portanto, o ser humano movido por fantasias ao realizar seus desejos utópicos, vale-se da técnica como função mediadora da natureza. Daí a relevância do sonho acordado ter maior magnitude em relação aos sonhos noturnos: esses oferecem caminhos indecifráveis da vida, Bloch diria "o castelo no ar não é um prelúdio do labirinto noturno; antes, são os labirintos noturnos que formam os porões do castelo diurno no ar". 8

O homo utópicus é um livre sonhador questiona seu sentido no mundo e sua condição junto à natureza, tem em conta que todo sonho acordado é passivel de alcançar e tornar-se concreto. A natureza está sempre a pta a responder conforme "uma possibilidade real objetiva" 9 , por estar sujeita à latência da matéria e à imanência de suas leis. A categoria da possibilidade revela na matéria as condições de potencialidade real. Münster lembra, em sua ontologia sobre Bloch, que a questão do "ainda-não-ser" tem como base a imanência e potencialidade da matéria que ainda não foi exteriorizada. ${ }^{10} \mathrm{O}$ que seria o ainda-não-ser de uma videira, seria apenas seus frutos? Além da uva, vinho, vinagre, graspa, geleia, resveratrol entre outros tantos produtos decorrentes de uma videira que resultam de sonhos acordados do homo utópicos ao desvelar o "que ainda-não-é". Assim, o que era apenas um sonho impossivel, passa a ser uma utopia técnica revelada, graças à mão laboriosa do homem junto à natureza.

Entretanto, há uma dependência do sujeito como agente que detém impulso na direção do sonho a ser concretizado; o sujeito é aquele que possui uma consciência antecipadora, que orienta e se projeta para um infinito na direção do futuro, isto é, que possui um alvo. Contudo, o que desafia o homem a sair do seu imobilismo é a categoria da possibilidade, esta transforma pela esperança o otimismo militante. ${ }^{11}$ Diante do avanço tecnológico a revelação de novas utopias técnicas questionam a todo o momento se tais artefatos poderiam dominar o ser humano? A tecnologia como necessidade se põe no mundo antropocêntrico como instrumento do homem para maximizar o poder não racional, determinando o homem apenas como meio, como um ser ausente do reino dos fins, regnus hominis. Essa é a condição, em que o ser humano não é mais representado pela racionalidade humana, mas pela racionalidade técnica ${ }^{12}$.

\footnotetext{
BLOCH. Ernst. Principio esperança. Tradução de Nélio Schneider. Rio de Janeiro: Editora UERJ/Contraponto, 2005. v. 2. p. 6-7. LIBÂNIO, Ibid., p. 70.

O pensamento utópico rompe a polarização entre os extremos do idealismo e do realismo, racionalismo e emocionalismo, empirismo e voluntarismo. Introduz novas variáveis ao falar de uma realidade (realismo) que se projeta para o futuro (idealismo), de um movimento da razão (racionalismo) que ultrapassa ao ser impulsionado pelo desejo, fantasia, imaginação (emocionalismo) e arranca do real e do presente (empirismo), mas se alimenta da fé nas possibilidades criativas e nobres do homem(

8 BLOCH, Ernst. Principio esperança. Tradução de Nélio Schneider. Rio de Janeiro: Editora UERJ/Contraponto, 2005. p. 89. v. 1.

9 Ibid., p. 303

10 MÜNSTER, Arno. Filosofia da práxis e utopia concreta. São Paulo: Edusp, 1993. p. 14.

11 FURTER. Pierre. Dialética da esperança. Rio de Janeiro: Paz e Terra, 1974. p. 150

12 GALIMBERTI, Umberto. Psiche e Techne: o homem na idade da técnica. São Paulo: Paulus, 2006. p. 792-794. O autor destaca que na modernidade o homem na idade da técnica tem consigo a queda do "reino dos fins kantiano", onde "o mundo dos seres racionais ldie Welt vernünftiger Wesen]" chamado também de mundus intelligibilis tem por princípio: "Age de tal maneira que uses a humanidade, tanto na tua pessoa como na pessoa de qualquer outro, sempre e simultaneamente como fim e nunca simplesmente como meio".
} 
A técnica se institui como linguagem entre o homem e a natureza, comporta-se como dimensão mediadora que instrumentaliza os sonhos acordados, mas avança e se sujeita a uma condição em que passa a dispor dos "meios como fins". A incompreensibilidade e a ignorância do homem sobre a condição de potência da matéria, o faz prescindir dos fins, caindo por terra à ideia de que o homem seja um fim em si mesmo. ${ }^{13}$ Essa inversão faz com que o homem transforme-se no meio e a natureza se comporte como sujeito, tratada como um fim em si mesmo. Sabe-se que o homem, ao trabalhar a natureza, nunca se comportou como seu aliado, mas sempre a tratou tecnicamente com violência. A técnica, embora habitando um universo da ciência, quando desconhece o ainda-não da matéria, é levado traduzir seus efeitos autárquicos como mera singularidade. Entretanto, a técnica, e a linguagem do homem com a natureza, comporta-se de forma irreverente e agressiva perante a natureza: Bloch considera que "[...] a técnica existente até hoje se posiciona na natureza como um exército inimigo e do interior do país não sabe nada, a matéria da coisa the é transcendental." ${ }^{14}$ Nesse sentido a técnica é a linguagem transformadora da matéria que transforma os sonhos acordados em utopias autárquicas. Por outro lado, o avanço tecnológico e os seus novos artefatos técnicos têm o poder de dominar o homem, na medida em que o universo das máquinas singulares (utopias autárquicas), no seu movimento silencioso, autonomia e determinar eventos contingenciais sujeitos a uma dominação externa.

Galimberti observa que o ser humano usa a sua inteligência, desenvolve uma "razão científica que se transforma em técnica"; ele explora os meios disponiveis da natureza, forjando sempre novos artefatos que respondem por objetivos que a mente do homem instrumentaliza não mais enquanto fins, mas como meios não racionais. A razão torna-se uma técnica para calcular os meios e disponibilidades para atingir certo objetivo. ${ }^{15} \mathrm{O}$ filósofo pressupõe que o domínio externo está sujeito a transformar o homem, não mais como fim, e sim como um meio para realizar os fins de determinado artefato. Nessa condição, a técnica inverte a relação e o homem se coloca apenas como meio e a natureza, como um fim em si mesma tornando as utopias autárquicas não mais um belo sonho acordado, mas um eterno pesadelo.

Pesadelos que nascem e renascem, na forma de utopias autárquicas são máquinas irracionais da natureza que dão origem a centrais nucleares, instrumentos radioativos, defensivos quimicos, autonomia da Inteligência Artificial robôs sociais, engenharia genética, entre tantas utopias que tornam- se distópicas, ausentes de um juizo moral, sem um saber normativo que orientem as ações éticas do homo utopicus.

\section{Categoria da possibilidade}

A categoria da possibilidade é base da ontologia de Bloch sobre as utopias. O filósofo considera a matéria anterior à forma e entende que matéria envolve homem e natureza e que ambos se projetam no infinito como ser-em-possibilidade determinando quatro niveis de possibilidade: nivel 1 (possivel formal), nivel 2 (possivel objetivo-factual), nivel 3 (possivel conforme à estrutura do objeto real), e nivel 4 (possivel objetivo real). "Nivel 1" - um possivel formal (Das formal Mögliche): "é o possivel do otimismo que ignora de propósito ou não os obstáculos e crê na possibilidade de um progresso linear" 16: conduz o ser a uma fantasia, a um vago utopismo, a uma visão irrealista impossivel de se realizar, mas possivel de se pensar. "Nivel 2" - possivel objetivo-factual (Das sachlich-objektiv Mögliche]. Considera que "o homem tem uma consciência-antecipadora de sua realidade onde

\footnotetext{
13 KANT, Immanuel. Fundamentação da metafísica dos costumes. Lisboa: Edições 70, 2008, p. 73-74.

14 BLOCH. Ernst. Principio esperança. Tradução de Nélio Schneider. Rio de Janeiro: Editora UERJ/Contraponto, 2005. p. 250. v. 2.

GALIMBERTI. Umberto. Psiche e Techne: o homem na idade da técnica. São Paulo: Paulus, 2006. p. 415. O autor prescreve que a emergência da razão científica aponta evidências que são os fins que, supostamente inscritos na natureza, eram apenas os meios pensados pela mente humana para dominar essa natureza; nesse sentido, a razão não nasce como um princípio imanente à realidade, mas como instrumentalização de que a mente humana dispõe para o domínio da realidade. A razão torna-se uma técnica para calcular meios e disponibilidades para atingir certo objetivo.

16 BLOCH, Ernst. Principio esperança. Tradução de Nélio Schneider. Rio de Janeiro: Editora UERJ/Contraponto, 2005. v. 2 p. 112.
} 
estão à possibilidade de previsão de se levantar problemas, imaginar soluções e desenvolver o domínio sobre o real." ${ }^{17}$ Nesse nivel habitam as utopias técnicas (Ars inveniendi). "Nivel 3" - possivel conforme estrutura do objeto real Tem origem na esquerda aristotélica, e a sua base está na virtualidade das coisas. Como traduz Furter, "o dinamismo da matéria por ter virtualidade (potência) refletirá o dinamismo da natureza que produz natureza, natura naturans, onde o homem passa a ser apenas uma caixa de ressonância." ${ }^{18}$ A perda de controle do artefato resulta do dinamismo da natureza, que utiliza sua potência imanente para gerar utopias autárquicas. "Nivel 4" - possivel objetivo-real. Bloch resolveu a antinomia sujeitoobjeto estabelecendo um equilíbrio hegemônico no par dialético instaurando o "nível 4" (possivel dialético). Furter observa que "a transformação do real só é possivel porque o realjá estava mudando; mas a intervenção humana é necessária para que esta transformação se torne desenvolvimento infinito." ${ }^{19}$ Ou seja, o dinamismo da matéria é cego, não possui consciência antecipadora, a qual vai ser dada pelo homem. Nesse sentido, o movimento se dá orientado para um alvo que só o homem tem condições de determinar, de modo que venha a existir uma completude entre os ambos "possiveis". Na ontologia de Bloch, a instrumentalização do mundo revela que a "dialética do possivel20" é a solução incompreendida diante dos impactos decorrentes da dinâmica da matéria e da atividade humana causando certa tensão na categoria da esperança esclarecida (Docta spes). Destaca-se que os niveis 2 e 3 se opõem, ora determinando o domínio do homem sobre a matéria-idealismo, ora da matéria sobre o homem. ${ }^{21}$ Albornoz identifica que no quarto nivel da categoria da possibilidade de Bloch estaria contido o dynàmei òn, a matéria dialética dinâmica, o ser-em-possibilidade, o menos determinado, a abertura do sistema ${ }^{22}$, onde está implícito a concepção de Bloch que a possibilidade real traz em si uma determinação do futuro.

Entre os quatro niveis de possibilidades sugeridos por Bloch, os niveis 2 e 3 parecem exclusivos e mutuamente estranhos: o nivel 2 porque pressupõe a capacidade de o ser humano realizar os seus sonhos diurnos, suas utopias, usando os limites de sua racionalidade instrumental, o que implica o domínio do homem sobre o homem e sobre a natureza; contrariamente o nivel 3 que identifica o movimento singular da natura naturata ao assumir a potência de uma natura naturans ${ }^{23}$, "natureza que produz natureza", impondo através de seus eventos o domínio da natureza sobre o ser humano, implicando nesta relação, uma possivel degeneração da matéria. Tais possibilidades "o possivel conforme a estrutura do objeto real" e "o possivel objetivo real" dialeticamente tendem reconciliar-se na totalidade hegeliana na plenificação do conceito. Embora ambos os níveis de possibilidades 2 e 3 sejam receptivos as contingências que cercam os artefatos utópicos diferem diametralmente nos seus efeitos em seus limites, um conduz a escravidão do homem, o outro indeterminado conduz a escravidão pela natureza.

\section{Natureza e suas máquinas irracionais}

A caverna de Platão sempre reaparece quando lidamos com os segredos da natureza. O avanço da ciência sempre gera sombras obscuras sobre os novos escravos da tecnologia. A emergência de utopias não euclidianas desenha novas figuras, demonstrando que a tecnologia é sempre um ainda - não perturbador, diante do possivel real. O que não era possivel, agora é real. Por outro lado, a recepção desses artefatos, desafia o ser humano para o mercado consumidor conduzindo-o homo sapiens à era dos novos descobrimentos. Podese indagar se o homem voltará caminhar passo a passo no andor primitivo? O mito deslumbrado em espelho mágico parece viver conjuntamente

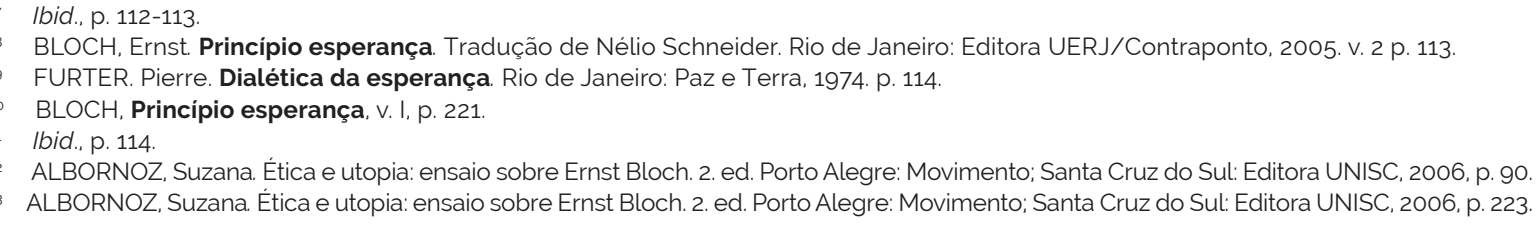


sozinho e isolado do mundo sem que ninguém ouça o grito mudo de seu apito. O fascínio pelas novas tecnologias e a oferta de artefatos desconhecidos não despertam a curiosidade do ser humano, como têm o dom de anestesiar as poucas referências éticas e a mora fugidia de seu tempo. O desconhecimento de seus efeitos perder-se no mundo secular, o que no dizer do filósofo Stein situa o humano no espaço da desreferenciação. ${ }^{24}$ revolução industrial iniciou a grande ruptura orgânica homem- natureza, anunciando- o prenúncio da pós- modernidade ${ }^{25}$, o domínio do homem, regnus homini, sobre a matéria enquanto natura naturans atendia a lógica de Francis Bacon do próprio homem.

O filósofo de Tübigen, ao destacar as utopias do nivel 3 no século XX, considera nesse nivel artefatos que fizeram eco na segunda guerra mundial, a eclosão das primeiras armas nucleares que determinaram o holocausto de Hiroshima e Nagasaki. A pretensa expectativa de cientistas sobre os efeitos produzidos nesses destes dois eventos estranhou não só o mundo científico, os físicos e engenheiros que desenvolveram tais artefatos, demonstrando posteriormente o desconhecimento do processo autárquico que revelou de forma imprevisivel o efeito devastador desses artefatos. Para Bloch, esse era o grande sinal do apocalipse, muito embora reconheça o salto da ciência, da mecânica newtoniana à física nuclear. Prescreve que "com esta tecnologia abandonase a própria mecânica palpável clássica: dentro do elétron não existe aparência de coisa alguma; elétrons e prótons não são mais a substância do antigo mundo físico." ${ }^{26} \mathrm{O}$ desenvolvimento da técnica instrumentalizou a matéria dando a conhecer sua potencialidade, dispondo de elementos que podem ser manipulados não só em proveito do ser humano como oferecer uma arma perversa. Tais eventos pontam que

a idade da técnica começa quando o uso da técnica não tem mais em vista uma finalidade (nem mesmo o lucro), mas só a própria potencialização. Isto só ocorre quando aparece claro que a obtenção de qualquer fim é subordinado à disponibilidade técnica e, por isso, a potencialização dessa disponibilidade termina por representar o único verdadeiro fim.

O Filósofo destaca que quanto mais à técnica perder os últimos resquícios da sua origem, quanto mais conquistar novas raízes nos espaços do mundo que quiser, mais ela se referirà à indústria da radioatividade e aos produtos sintéticos. Esses eventos questionam se as utopias não euclidianas são capazes de libertar o homem ou torna-lo mais escravo? Sugerindo um novo questionamento. Estariam os seres humanos tendendo mais para o reino da liberdade ou para o universo das necessidades?

As utopias técnicas podem escrever a história do mundo. Se lançar as luzes sobre utopias aristotélicas (envolve os sentidos), utopias baconianas (homem industrioso) e utopias não euclidianas (manifestam autonomia da matéria ${ }^{27}$ ) quando emergem são acolhidas e festejadas na racionalidade do mercado. Nesse contexto subjaz o radicalismo da subjetividade humana, onde o que menos importa é amplitude das desigualdades ou o pior que seus efeitos oferecem, incertezas ao ambiente cosmocêntrico.

A questão que se põe é: como explicar que o homem possa gerar uma máquina irracional da natureza com graus de autonomia, construindo um universo de utopias autárquicas sem conhecer a linguagem da "unidade originária". Linguagem que, embora desconhecida diz-se por seus efeitos e se outorga como agente legislador capaz de gerar um novo sujeito produzindo insondáveis dilemas éticos a seu criador.

\section{Utopias Autárquicas}

As utopias autárquicas são utopias não euclidianas que possuem o poder próprio, tem autonomia trazem nos seus feitos revelam os mistérios respondem por si a natureza ainda

\footnotetext{
STEIN, Ernildo. Errar e pensar: um ajuste com Heidgger. ljui: Ed. Unijui, 2011, p. 181.

LATOUR, Bruno. Jamais fomos Modernos: ensaio de antropologia simétrica. Rio de Janeiro: Ed. 34, 1994. p. 12-17.

BLOCH, Ernst. Principio esperança. Tradução de Nélio Schneider. Rio de Janeiro: Editora UERJ/Contraponto, 2005. p. 216. v. 2.

FOSSATTI, Nilson. Utopias técniças: Ars Inveniendi - Além da organicidade. In: SOUZA et al. (org.). Ernst Bloch: atualidade das utopias concretas. Porto Alegre: Editora Fi, 2016, p. 213-236. v. 1.
} 
desconhecida. Essas utopias produzem eventos inesperados e têm uma causa-sui desconhecida cujas contingências são imprevisiveis; a todo o momento podem concorrer para ameaçar a vida e gerar catástrofes ao meio ambiente. Portanto, o alvorecer do homo utopicus, através da técnica está ai-e-agora, oferecendo riscos a casa comum, sem uma ancoragem moral, ausente de uma esfera ética. Portanto, cabe repensar ética para o homo utopicus, bem como, despertar a técnica para o caminho de reconciliação da unidade originária. É urgente refletir sobre ausência de pressupostos éticos, não mais da potência tardia do sujeito sua ars inveniendi mas diante da potencialidade da matéria liberada pelo homem. A técnica conduz a matéria produzida - natura naturata, esta não pode vestir a capa da natura naturans para se transformar (ainda-não-é) em natureza produtora de natureza produzindo incertezas no mundo cosmológico.

As utopia autárquicas que emergem no $3^{\circ}$ nivel (possibilidade conforme a estrutura do objeto real) passa a ser o locus onde as utopias autônomas. Bloch ao fundamentar sua ontologia da possibilidade demonstra que o homem. matéria dinâmica não era o único capaz de despertar o dinamismo da natureza criadora; não era o único que detinha o poder gerar uma nova natureza natura naturans. Por muito tempo o homem, enquanto senhor do mundo, deteve o poder de utilizar apenas matéria revelada natura naturata esta sempre foi meio para atender o fim último intervir nos segredos desconhecidos da natureza. Entretanto o processo ars inveniendi demonstra a presença do caráter instrumental e sua indiferença, uma dualidade que revela a forma perversa, tanto na objetividade quanto na sua subjetividade. Assim quase toda relação que o homem desenvolve junto à natureza sem conhecer sua linguagem está sujeito a um paradoxo da unidade originária ora o homem domina a matéria, ora a matéria domina o homem. Demonstrando que processo de interação homem-natureza carece de transparência ética, envolvendo a pretensão instrumental do homem.

A resposta para minimizar os efeitos da autonomia da matéria sobre o ser humano encontra recorrência quando se instala o processo dialógico orgânico na relação sujeito-objeto. Nessa condição o movimento dialético de origem na inquietude do ser humano, ao transformar infinitamente a matéria (a incompletude do ser-aí) tem como impulso a esperança compreendida presente no determinismo orientado pelo homem. Um contexto que questiona a radioatividade, Inteligência Artificial: self driver, robô social.

\section{Radioatividade}

É preciso destacar que a natureza permanece em aberto para um ainda-não e para um poderser [kann-sein]; a matéria como homem, à natureza, assim como a sociedade, tende para o que ainda-não pelos aspectos possíveis que neles se desenvolvem." ${ }^{28}$ A ciência endeusada e a sua aplicação prática através da técnica faz repensar o sentido do homem no mundo e a resposta para esse questionamento só é dada quando o sujeito torna-se capaz de pensar a si mesmo. ${ }^{29}$ Por outro lado, as utopias autônomas são trilhas de incertezas produzidas pelo avanço da ciência e pela adoção de novas tecnologias que fugiram ao controle do ser humano. Portanto, são resultados da ruptura do real em quanto livre sujeito da natureza. Portanto, toda forma de natureza utópica presente no cosmos, gerada pela mão do homem, pode assumir um poder autárquico gerar contingências boas ou más Considerando problemas no âmbito da energia nuclear, a natura naturata (condição do urânio) quando assume a condição de produzir natureza torna-se a mais eloquente das utopias autônomas. Fatos conhecidos demonstram que até hoje seus criadores estão sujeitos a fracassarem na gestão de elementos radiativos. No Brasil, a radioatividade gerada por equipamentos de radioterapia são utilizados causando efeitos futuros incontroláveis. O césio 137, em Goiana, deixou sequelas nos pacientes refletindo em 
órgãos humanos e resultando na morte de seis pessoas e contagiou mais de 1200 pessoas. No mundo, mais de dez ${ }^{30}$ usinas nucleares foram acidentadas, demonstrando que os recursos explorados da natureza ainda não são de pleno controle do homem e representam um potencial perigo à humanidade. O Efeito Borboleta poderá ser devastador se continuarem os eventos semelhantes aos de Chernobyl. A usina nuclear Daiichi, em Fukushima (Japão), de 1986, ainda é uma ameaça à humanidade.

O físico Sergei Anatolyevich Paschuk ao analisar o verdadeiro holocausto da usina nuclear, declara que "antes do desastre ninguém fazia conta do poder desta tecnologia. Hoje é preciso pensar nas "consequências" destes artefatos." Os índices de radiação atual continuam a contaminar o leite, os cogumelos as verduras e mais de cinco milhões de pessoas já foram contaminadas pela radioatividade. Os efeitos incalculáveis desses artefatos demonstram uma visivel preocupação da humanidade, que se sente insegura diante de utopias que ameaça a terra e o cosmo com seus efeitos imprevisiveis.

A ciência, ao desvendar os segredos do átomo, e o homem, ao se apropriar de tais recursos criam utopias impensadas, fontes de energia elétrica que perderam o controle de seus artefatos (Power Station) que geraram dez eventos catastróficos ${ }^{31}$.

Em 2020, os campos de Chernobyl queimam ea fumaça radiativa ameaça três milhões de moradores de KIEV. O incêndio florestal atingiu a região de a antiga usina nuclear de Chernobyl, na Ucrânia.
Fumaça radioativa se aproxima de Kiev. capital do país. Apesar da ameaça e do medo dos moradores locais, em nota publicada numa rede social, Plachkov garante que ao chegar em Kiev, onde vivem cerca de 3 milhões de pessoas, as concentrações de material radioativo (césio-137) devem atingir concentrações inofensivas à vida e à saúde da população ${ }^{32}$

Pode-se observar que a ciência, ao desvendar os segredos do átomo, e o homem, ao apropriarse de tais recursos deu a luz a novas utopias, gerando contingências ainda impensadas. Assim demonstram as fontes de energia elétrica (Power Station) que perderam o controle gerando dez eventos catastróficos no mundo ${ }^{33}$.

No âmbito da área médica, recursos de raio $x$, raios-, tomografias e ressonâncias magnéticas, inicialmente aceitas pela comunidade médica, têm posteriormente sido questionadas por exagero de suas aplicações devido aos efeitos radioativos cumulativos no tempo principalmente quando mal direcionados no cérebro determinando um conflito ético que pendula o utilitarismo e o imperativo kantiano, postergar a vida e alienar o ser humano.

\section{Inteligência Artificial}

Uma das maquinas emergentes deste século refere-se ao grande "holos", é uma das utopias que se propõe ser a mente global ou noosfera. Uma inteligência coletiva de todos os seres humanos que será combinada com o comportamento coletivo de todas máquinas ${ }^{34}$. fará com que o mundo seja conduzido para outro habitat e, desse modo, viver no mundo virtual não será

\footnotetext{
30 Chernobyl na Ucrânia; Three Mile Island (Pensilvânia); usina nuclear Daiichi em Fukushima (Japão); vazamento de urânio em uma instalação nuclear secreta perto de Erwin (Tennessee); na usina nuclear de Tsuruga (Japão); Tomsk (Rússia); Tokai (nordeste de Tóquio); usina nuclear de Mihama (Japão); Tricastin na França.

${ }_{31}$ Em Three Mile Island uma falha humana impediu o resfriamento normal de um reator, cujo centro começou a derreter. Os dejetos radioativos provocaram uma enorme contaminação no interior do recinto de confinamento destruindo $70 \%$ do núcleo do reator. Um dia depois do acidente um grupo de ecologistas mediu a radioatividade. Sua intensidade era oito vezes maior que a letal. Cerca de 140 mil pessoas foram evacuadas das proximidades do local. $\mathrm{O}$ acidente foi classificado no nivel 5 da escala internacional de eventos nucleares (INES) que vai de 0 a 7.

32 Disponivel em: https://www.otempo.com.br/mundo/fumaca-radioativa-de-incendio-em-chernobyl-se-aproxima-da-capital-da-ucrania-1.2323595. Acesso em: 0404/2020. O Tempo Seta Mundo. Destaca AMEAÇA NO AR. Fumaça radioativa de incêndio em Chernobyl se aproxima da capital da Ucrânia. Os residuos das chamas que destruíram cerca de 35 hectares após três dias de incêndio na região da usina nuclear levou à evacuação dos moradores da vila Polesskoye, perto de Chernobyl. Conforme Egor Firsov, que lidera o serviço de inspeção ambiental, a radioatividade no coração do incêndio é superior à normal".

33 Em Three Mile Island uma falha humana impediu o resfriamento normal de um reator, cujo centro começou a derreter. Os dejetos radioativos provocaram uma enorme contaminação no interior do recinto de confinamento destruindo $70 \%$ do núcleo do reator. Um dia depois do acidente um grupo de ecologistas mediu a radioatividade. Sua intensidade era oito vezes maior que a letal. Cerca de 140 mil pessoas foram evacuadas das proximidades do local. O acidente foi classificado no nivel 5 da escala internacional de eventos nucleares (INES) que vai de 0 a 7.
}

34 
mais utópico; viveremos dentro da máquina e seremos a própria máquina Essa mudança prevista para meados do ano 2030, em que a máquina de processamento deverá ter, no mínimo, a mesma quantidade de neurônios de um ser humano. Essa mudança radical denominada "singularidade", conceitua o periodo em que a natureza vai gerar natureza, e o homem poderá ser definitivamente dominado pela matéria. A tecnologia se desenvolve principalmente nas áreas neurológicas, conforme Kurzweil relata: vinte regiões do cérebro humano já foram modeladas e simuladas. Em sua obra The Singularity is Near, ele cita algumas empresas que estão construindo córtex cerebrais, oferecendo uma percepção de nós mesmos. ${ }^{35}$

Nicholas Carr, na sua obra The Shallows ${ }^{36}$, destaca que há concorrência feroz para tornar a vida das pessoas mais fácil, alterando a obrigação de resolução de problemas e deixando outros trabalhos mentais longe do usuário, repassandoos para o microprocessador. Observa o autor que a dependência tecnológica está cada vez mais sendo incorporada no comportamento dos individuos. ${ }^{37}$ A empresa Dodge denomina "sistema único e maior" o dispositivo de processamento de dados que permite realizar certas tarefas cognitivas de forma mais eficiente, sistema esse que também representa uma ameaça à nossa integridade como seres humanos.

\section{Robô social}

O maior sistema dentro de cada uma das nossas mentes está prontamente apto a fundirse e, concomitantemente, está impondo os seus poderes e ditando nossas limitações. Carr lembra a frase de Culkin: "nós programamos nossos computadores e depois eles nos programam". ${ }^{38}$ O sonho das pessoas em possuir robôs sociáveis demonstra uma utopia técnica que consiste em responder à solidão do ser. De acordo com Turkle39, "o robô irá proporcionar companheirismo e mascarar nossos medos de arriscadas intimidades. A ideia de um robô companheiro serve tanto como sintoma e sonho. Como todos os sintomas psicológicos, ele obscurece um problema de 'resolução' sem abordá-lo." 40 A máquina parece mudar a forma de relação entre duas pessoas e, consequentemente, o conceito de amor. Turkle destaca mais as vulnerabilidades do ser humano do que as suas necessidades que implicam ter alguma coisa. A tecnologia pode e parece que vai assumir e monitorar o ser humano ${ }^{41}$.

Por outro lado, Dawkins, observa que "as máquinas futuras serão humanas, mesmo que sejam biológicas, por conseguinte, a maior parte da inteligência de nossa civilização será basicamente não biológica." 42 É a máquina determinando e selecionando os que terão melhor qualidade de vida e os que estarão sujeitos ao processo natural. Numa carta a Charles Darwin, Samuel Butler

\footnotetext{
3541 KURZWEIL, Ray Theingularity Is Near: When Humans Transcend Biology. Nova York: Viking, 2005, p 30-35.

CARR, Nicholas. The shallows. New York: Norton Paperback, 2011, p. 216. O autor referindo-se a empresa Dodge que adotou o conceito de "sistema único e maior", o dispositivo de processamento de dados que permite realizar certas tarefas cognitivas de forma mais eficiente e também representa uma ameaça à nossa integridade como seres humanos. O maior sistema, dentro de cada uma das nossas mentes, está prontamente apto a fundir-se e, ao mesmo tempo, está impondo os seus poderes e ditando nossas limitações.

37 Ibid., p. 216. "Julia diz para sua mãe onde ela está em todos os momentos. Se sair, liga; ela diz que "é realmente dificil pensar em não ter o seu telefone celular". Eu não poderia imaginar em não ter o celular [...]. Eu sinto que ele está anexado em mim. Eu e meus amigos dizemos: 'Eu me sinto nua sem ele'"'.

38 CARR. Ibid., p. 214

39 TURKLE, Sherry. Alone together: why we expect more from technology and less from each other. New York: Published by Basic Books, 2011. p. 283. Robôs revelam o nosso desejo de relacionamentos como algo que podemos controlar. Se a vida online é rigorosa, o robô estará sempre ao nosso lado.

${ }_{40}$ TURKLE, Sherry. Alone together: why we expect more from technology and less from each other. New York: Published by Basic Books, 2011. p. 283 "A ideia de ser vulnerável deixa muito espaço para a escolha. Há sempre espaço para ser menos vulnerável mais envolvido. Nós não estamos presos. Para avançar juntos - como gerações juntas - somos chamados a abraçar a complexidade da nossa situação. Nós inventamos tecnologias inspiradoras e exageradas e, ainda assim, nós permitimos que nos diminuissem. A perspectiva de amar ou ser amado, uma máquina muda o que o amor pode ser. Nós sabemos que os jovens são tentados. Quem conhece o tempo de vida de amor certamente pode oferecer mais".

41 Ibid., p. 303. Você pode intervir; por exemplo, você pode codificar manualmente as coisas mais importantes que você faz ou aquelas que fazem com menos frequência. Você pode dizer que as raras ligações são para as pessoas mais importantes. Mas Life Browser vai entregar, de acordo com seu real comportamento, e atender suas prioridades. Horvitz, demonstrador do programa, diz que "se trata de compreender como funciona a sua mente, como você organiza as memórias, com o que você escolher. Ele aprende a ser como você é, e tem como objetivo ajudá-lo a ser uma pessoa melhor." Turkle lembra que é normal as empresas instalarem nos computadores o Browser Vida, um software que observa o que você pretende - os arquivos que você abre os e-mails que responde as buscas da Web que você faz. 42 DAWKINS, Richard. O gene egoísta. Tradução de Rejane Rubino. São Paulo: Companhia das Letras, 2007, p. 29.
} 
indagou: "quem será o sucessor do homem"? A resposta foi: nós mesmos estamos criando os nossos sucessores. O homem se tornará para a máquina o que o cavalo e o cão são para o homem; sendo a conclusão que as máquinas são ou estão se tornando animadas ${ }^{43}$.

Alguns cientistas esperam que a humanidade possa viver uma grande ruptura; alguns concebem a ideia de uma nova singularidade para o século XXI, principalmente no campo social-políticoeconômico e na dimensão moral. O ser dinâmico encontra-se em estado de mutação, há sempre uma refundação gradativa do ser, considerando que a possibilidade real não reside numa ontologia acabada do ser e do que existiu até o momento, mas na ontologia a ser renovadamente fundada no ser do ainda-não existente que descobre o futuro até mesmo no passado e na natureza como um todo. ${ }^{44}$ Em sua ontologia, a categoria da possibilidade torna-se importante no instante em que a matéria detém condições de potencialidade e possibilidade de se realizar. Vinge parece prospectar um progresso comandado por uma inteligência superior a humana quando prediz:

Dentro de trinta anos teremos os meios tecnológicos para criar uma inteligência super-humana. Pouco depois, a era terá terminado. Será que esse progresso é evitável? Quando uma inteligência superior à humana impulsionar o progresso, este será muito mais rápido. $\mathrm{Na}$ verdade, parece não haver nenhuma razão para o próprio progresso não envolver a criação de entidades ainda mais inteligentes numa escala de tempo ainda mais curta.

O desenvolvimento de um sistema Holos capaz de abrigar uma inteligência super-humana, e superar a capacidade cognitiva do homem avança exponencialmente valendo-se de sistemas autônomos que possuem aprendizado de máquina (machine learning), utilizando recursos de Inteligência artificial, atendendo uma visão geopolítica de agilizar o progresso no mundo.
Contudo tais máquinas podem oferecer o nexo causal para uma distopia técnica em que máquinas e sistemas de processamento mecanizem o homem passando a ser mais meio do que fim mais escravo do que livre e dependente de uma inteligência artificial.

Nesta perspectiva, torna-se imperativo a busca de mais conhecimento para realizar seus sonhos utópico atendendo a máxima de Francis Bacon "conhecimento é poder" o avanço tecnológico tem reflexos político social e econômico, certamente será positivo para fortalecer os niveis de poder, o autoritarismo, abrindo um mercado de trabalho promissor a emergência da $4^{\text {a }}$ revolução Industrial e aos gentios que habitam mundo dos algoritmos.

A emergência de uma nova Utopia de Ore ${ }^{45}$ estimula novos pesadelo de sonhos acordados, as perversões da economia centralizada, enfraquecem os direitos humanos, ausência de privacidade, tendem a estabelecer controles e impor limites a liberdade do homem. O mundo científico observa com espanto a capacidade do ser humano de produzir tais artefatos principalmente as utopias autônomas. Entretanto, parece não questionar u ficar alheio ao impacto diante dos niveis de liberdades desses artefatos que ainda não são tipificados em lei. A inteligência artificial combinada com a internet permite conviver com utopias dotadas de autonomia, porém ausente de uma fundamentação ética que ainda não se apropriou de uma distinção teleológica e/ ou deontológica.

\section{Self driver}

A perspectiva de que carros, caminhões e motos sejam autônomos e disponiveis na década de 2020, é uma realidade nos EUA, Europa e no Japão. Lin, filósofo e gerente do "Grupo de Ciências de Ética e Ciências Emergentes da Universidade Politécnica da Califórnia", reconhece "as máquinas autônomas" como os primeiros

43 KURZWEIL, Ray. Theingularity Is Near: When Humans Transcend Biology. Nova York: Viking, 2005 p. 32 . Estima que em 2029 a computação será suficiente para simular todo cérebro humano estimado em 10 bilhões de cálculos por segundo (cps) e custará menos de um dólar. Lembra que as máquinas inteligentes combinarão as capacidades de reconhecimento de padrões com precisão, e poderão fazer buscas em bancos de dados, fazer download de habilidades e de conhecimento.

44 BLOCH. Princípio Esperança, v.2, p. 233-234.

45 ORWEL, George. 1984. Trad. Wilson Velloso. 16 ed. São Paulo: Ed. Nacional, 1983. 
robôs sociais que circulam na sociedade. ${ }^{46}$ Lin observa que se fosse passageiro de um carrorobô não estaria disposto a dar a sua vida para salvar uma ou duas vidas, se ele tivesse sujeito a uma decisão no interior do carro. Em caso de acidente com um carro autônomo, quem seria o culpado? Por que pensar que os carros autônomos precisam ser programados para fugir da morte e programá-lo para decidir entre idosos ou crianças? Pode o carro autônomo através de um software decidir quem eventualmente poderia matar no acidente de trânsito? De acordo com Lin, "o usuário destes carros robôs tem o direito de não ser morto, podendo atropelar alguém para não ser a vitima de trânsito. ${ }^{47 "}$ Ainda se pode prever outros problemas com o dito carro autônomo, tais como situações de emergência, infrações, roubo, falha de equipamento. O carro está programado para não cometer acidentes; entretanto, o passageiro poderá pagar esse custo. Poderemos estar nos aproximando da teoria do caos ou do Efeito Borboleta? Entretanto, há uma questão que permanece em aberto no âmbito da filosofia: Qual a ética para as máquinas autônomas? Na atualidade esses exemplos apontam a autonomia de utopias técnicas como sendo indesejáveis à preservação da natureza. A inteligência do ser humano parece ausente diante da natura naturans.

A visão pessimista aponta para máquina capaz de reproduzir a si mesma e afrontar seu criador. poderia ser o caos. Contudo, a visão otimista entende o avanço da tecnologia exponencial e pressupõe que a máquina apenas, deve funcionar respeitando parâmetros pré-definidos, não devendo assumir niveis de cognição para agir como seres humanos, nem seres humanos deverão ser alienados agir como máquinas dependentes.

CASE. Autor da obra Calm Technology: entende que a tecnologia funciona bem quando podemos ignorá-la, assim como um bule de café está pronto e nos diz que está desligado. ${ }^{48}$.
Máquinas podem comunicar, mas não falar; deve ser um agente de tranquilidade e não de estresse; nossa atenção é muito importante para preocupações com tais artefatos. Atualmente, as redes sociais tornaram-se um sistema que de forma autônoma pode assumir a gestão e a vida dos seres humanos. Entretanto, a falácia de que para acabar com a solidão é só filiar-se a uma rede social parece vingar e, assim, verifica-se que adolescentes estão mascarando o sentido do homem como animal social mediante a uma vida virtual solitária, é a emergência de uma nova classe que se radicaliza como párias sociais.

Em relação à inteligência artificial, Teixeira 49 entende que há objeções levantadas por alguns teóricos contra a amplitude da IA afirmando que existem características humanas que não poderiam ser replicadas pelas máquinas. Trata-se hipótese abandonada, pois os virus se autorreplicaram e podem se multiplicar, além de terem a capacidade de mudar de forma por semelhança aos vírus dos seres vivos.

Em tempo é preciso desvelar o véu da ignorância que oculta a linguagem da natureza que opera os artefatos sonhados pelo ser humano. Prescinde um problema moral que cobra uma postura ética diante de tais artefatos. Talvez máquina singular, dotada de uma superinteligência, pudesse superar o ser humano. Nessa perspectiva, Bostrom advoga um princípio ético que ofereça mais garantias. $O$ principio do bem comum: Uma superinteligência deverá ser desenvolvida apenas para o beneficio de toda humanidade e a serviço de ideais éticos amplamente compartilhado por todos. ${ }^{50}$

A deia de uma superinteligência preocupa a comunidade científica, considerando a capacidade potencial de processamento de um sistema centralizado. Por ser capaz receber atributos humanos e não humanos e representar comportamento semelhante ou superior ao ser humano, pode livrar o homem de trabalhos repetitivos, podendo

\footnotetext{
LIN et al. Robot Ethics: The Ethical and Social Implications of Robotics, p. 21-22. 
postar- se mais que um assessor do ser humano; tal sistema autômato seria mais um decisor ao ter informação latente e raciocinio lógico desenvolvido não emocional. Um artefato nessas condições tem o poder tornar-se um tomador de decisões, embasado em conhecimentos, memórias cumulativas e machine learning.

Kurzweil destaca que o mundo entrou na "era das máquinas espirituais a inteligência artificial cresce de forma exponencial e se apresenta conforme a estrutura do objeto real concreto, o objeto desafia o espírito, haja vista que pode ser capaz de tomar suas próprias decisões.

Se as utopias autárquicas tomarem suas próprias decisões não será possivel fazer nenhuma conjectura quanto aos resultados futuros ou supor como essas máquinas poderão se comportar. ${ }^{51}$ Embora existam aspectos contingenciais imprevisiveis, a rede inteligente terá que atender às necessidades básicas do ser humano. ${ }^{52}$ Nesse sentido, tem que atender pela ordem: sua necessidade (condição de longevidade), em troca de liberdade, depositando, assim, aos pés da natureza, a sua maior riqueza: a subjetividade. Haverá sempre o risco de o sujeito indefeso estar na mão de uma elite que pode ser impiedosa. ${ }^{53}$ Está inclusa a possibilidade de uma superinteligência com objetivo de dominar artefatos que, subliminarmente, poderão escravizar o homem, com o risco de trocar sua liberdade por sua necessidade.

\section{Uma linguagem para unidade originária}

Quanto tempo o homem levou para decifrar a linguagem do fenômeno El Niño? Quanto tempo o homem levou para ser surpreendido pela linguagem de um elemento radioativo? Quanto tempo o ser humano levou para entender os efeitos da poluição atmosférica?
Que leitura a comunidade científica faz diante dessas catástrofes, maremotos, furacões, marés vermelha, aquecimento da calota polar sem dialogar com a natureza?

Há uma linguagem oculta na unidade originária que precisa ser desvelada para a segurança da humanidade. Essa tese tem como uma das referências a obra Ideias para uma filosofia da natureza, de Schelling, o filósofo que ousou utilizar o "princípio do caminho inverso" ao pensar as coisas exteriores ao observador. Invés de apenas nós agirmos sobre a natureza Schelling propõe "façamos a tentativa inversa: deixemos as coisas exteriores agirem sobre nós e, então, expliquemos como é que, ainda assim, chegamos a perguntar como é possivel haver em nós tais representações". ${ }^{4}$

Schelling ao fazer o caminho inverso faz o objeto vir à consciência do ser humano e recepciona na sua consciência a representação do real. $O$ filósofo em seu idealismo objetivo, entende que desta forma integra "natureza e espírito", uma condição que concebe sujeito e objeto sem que haja opostos. O ser nunca está acabado, se realiza de forma permanente no dinamismo da matéria; (há no ser um ainda-não realizado), neste sentido o espírito é natureza e natureza é espirito. Idealismo objetivo tematiza a liberdade interior da própria natureza, concorrendo para a emergência de elementos fundantes imprevisiveis que podem implicar o antropocentrismo radical, inconsequente e instrumental que traduz o berçário das utopias autônomas do homo utopicus. Esta perspectiva precisa ser desvelada existe uma voz muda da natureza que o ser humano desconhece geradora de utopias autárquicas.

Os exemplos de utopias autárquicas, sonhos impossiveis que o homem, utilizando sua tecnologia, desenvolve junto à natureza podem

\footnotetext{
51 McCORDUCK. Machines Who Think: a personal Inquiry into The History and Prospects of Artificial Intelligence. Massachusetts: AK Peter Ltd, 2004.

52 KURZWEIL. A era das Máquinas espirituais, p. 243-244. No futuro podemos atingir um estágio em que os seres humanos poderão vir a ser suplantados pelas máquinas em algumas tarefas. As pessoas estarão tão dependentes que não serão capazes de desligá-las. 53 Ibid., p. 244. Se a elite for impiedosa poderá decidir exterminar a humanidade e poderá usar técnicas psicológicas ou biológicas para reduzir a taxa de natalidade e decidir exterminar a massa da humanidade deixando o mundo só para a elite. Entretanto, se a elite for constituida de liberais de coração, eles poderão desempenhar o papel de bons pastores para o resto da raça humana. Naturalmente a vida será tão sem sentido que as pessoas terão de sofrer um processo de engenharia biológica para remover sua necessidade de poder ou sublimar seu impulso de poder em algum hobby inofensivo. Estes seres humanos poderão ser felizes nesta sociedade, mas certamente não serão livres. Eles terão sido reduzidos ao status de animais domésticos.

54 SCHELLING, Friedrich Wilhelm Joseph von. Ideias para uma Filosofia da Natureza, 2001. p. 46-49.
} 
ter resultados indesejáveis: centrais nucleares, aquecimento atmosférico, defensivos químicos, verdadeiras máquinas irracionais cujas respostas imprevistas sugerem que toda natureza é composta porverdadeiras máquinas portadoras de uma lógica própria ainda desconhecida pelo homo sapiens.

Quando em seu estado natural ou provocadas pela intervenção do homem na natureza apresentam, surpresas respostas imprevisiveis, parecem pensar suas respostas, demonstrando ao homem a possibilidade dialógica com a natureza que pode ser dada pela representação e exteriorização de uma forma de subjetividade.

Norbert Wiener, o pai da cibernética, preocupava-se como o mundo cibernético enquanto ciência. Para o cientista, buscar o sentido na relação dos fenômenos no mundo é relevante à medida que o pensamento se organiza em torno da ideia segundo a qual a "natureza" autêntica de qualquer ser observável, quer pertença à família dos seres vivos, das máquinas ou da natureza em geral, residia internamente nas relações, ou seja, na troca de informações que mantinha permanentemente com outros seres que povoam o seu meio ${ }^{55}$; Wiener antecipava sua singularidade, a pretensão do sistema "holos" referido anteriormente, ou do Ponto Ômega ${ }^{56}$, uma outra singularidade que cientistas intencionam descobrir; a perspectiva aponta para a ruptura do mundo com o mundo. o que significa pensar o mundo sob outro ponto de vista, um novo referencial, um ambiente cosmocêntrico. Segundo Gardner, esse enfoque se alinha ao pensamento do expansionismo tecnológico no qual "nosso cosmos pode ser uma espécie de computador natural gigante rodando, o que chamo de Software de Tudocódigo cósmico, conjunto de constantes físicas, leis naturais que estranhamente são favoráveis à vida." ${ }^{57}$ Revela que o universo é plural e possui uma diversidade que deve ser respeitada pelo ser humano. É preciso traduzir a sua linguagem e o seu algorítmo lógico na história do tempo

Torna-se necessário fazer uma crítica ao procedimentalismo que deve buscar a pretensão de universalidade. O mundo formado por comunidades no dizer de Cortina ${ }^{58}$ é preciso reconhecer com as éticas substancialistas, que as pessoas vivem e são necessariamente implantadas em comunidades e em tradições concretas. Há muito que resgatar no âmbito das comunidades tradicionais, implicando o repeito às diversidades e seu mores cultural-social.

Neste contexto, utopias autárquicas são consideradas como máquinas irracionais. entretanto, são portadoras de uma racionalidade lógica e capazes de manifestarem-se de forma imprevisivel podendo ameaçar a humanidade. Tais artefatos não pensam, não possuem a faculdade de legislar, manifestam-se através de elementos da natureza, são processados logicamente por um sistema integrado, desconhecido que desenvolve uma forma de autonomia.

É possivel pensar que tais máquinas são irracionais porque o ser humano ainda não dispõe de aparato tecnológico para desvendar a linguagem da natureza. Entretanto, o homem, ao contemplar a singularidade da terra, suas florestas, mares, rios. Os fenômenos do universo, o movimento dos planetas, estão sempre desafiando e questionando a lógica racional da unidade originária.

A ciência, ao pesquisar o passado, sabe que a natureza tem prescrito no seu interior um algoritmo oculto que aos poucos está sendo revelado por sua objetivação e exteriorização e latência da matéria.

Pode-se pensar que a ciência, ao decifrar os algoritmos da natureza está construindo uma nova linguagem possivel de diálogo, cujas raizes são tangidas no rastro cuidadoso de Epimeteu. Os exemplos demonstram que a interação homem natureza e sua cuidadosa historicidade tornou-

\footnotetext{
5 BRENTON: PROLUX. A explosão da comunicação, p. 104

TRIPLES; BARROW. The Anthropic Cosmological Principle, p. 103-106. Na obra de Horgan, o Fim da Ciência, considera que o "ponto ômega" é uma forma de singularidade; questiona-se, assim, o que aconteceria se máquinas inteligentes convertessem todo universo em um gigantesco dispositivo de processamento de informações. É preciso lembrar que, no cosmos fechado, a capacidade do universo de processar as informações se aproxima da infinitude, tendendo para uma singularidade final, o ponto ômega.

57 GARDNER. O universo inteligente: inteligência artificial, extraterrestres e a mente emergente do Cosmos, p. $29-33$.

58 CORTINA, Adela; NAVARRO Emilio Martinez. Ética. 6. ed. São Paulo: Edições Loyola Jesuítas, 2015. p. 112-113.
} 
se o caminho natural para revelar à verdadeira linguagem da matéria.

"O próprio sujeito da concessão do ser- aí, ainda não está aí; ele não está qualificado, não está objetivado, não está realizado, manifestandose em última instância na obscuridade do instante vivido. ${ }^{59}$ "Contudo, é esta obscuridade fugaz que deverá ter o compromisso de receber as luzes da história para traduzir a matéria objetivada. Assim, o cuidado com a técnica adotada não só poderá revelar o ser-aí, oculto na matéria, como deverá oferecer as causas e efeitos que ainda tornam os sonhos em pesadelos acordados.

O ser humano pode ser penalizado pelo avanço descontrolado da técnica, ora em busca de seus benefícios ou valores incertos ora assombrados pelas catástrofes descuidos e descontrole sobre a matéria objetivada. Entretanto há uma linguagem que se esconde, se apresenta e que não é revelada em nossa representação. Uma linguagem que uma vez explicita poderá permitir, um diálogo seguro entre sujeito e objeto embora, o ser humano ainda possa estar vivendo paixões impostas pelo mundo vivido.

A capacidade do ser humano é rica em produzir utopias autônomas, mas é devedora de uma ética que tem impactado o mundo científico. Institutos de pesquisas observam com espanto a trajetória de certas invenções que se manifestam silenciosamente, causando ameaças permanentes aos seres humanos. Sabe-se que os questionamentos emudecem diante de interesses no dizer de Habermas "não racionais e não argumentativos"; Contudo considerando os níveis de liberdade desses artefatos, seus impactos ainda não respondem aos imperativos éticos albergados nos foros da lei. Nesta perspectiva somente quando a ciência ouvir a "fala muda da natureza" será possivel reconciliar em parte a unidade originária. Nesta perspectiva pode-se pensar que as vozes mudas da natureza se apresentam ao ser humano através do olhar desafiador de Epimeteu.

\section{Considerações finais}

O dinamismo da matéria (natura naturata) põe à ética frente ao desconhecido, bem como, suas contingências geradas pelo seu progresso dialético do desconhecido, determinando a riqueza do universo gerador de utopias autárquicas, imprevisiveis, incontroláveis.

Considerando os efeitos das utopias técnicas Ars Inveniendiðo verificou-se a vocação do homo utopicus pela apropriação de máquinas não euclidianas, capazes de gerar eventos singulares e dinâmicos.

Em seu posfácio, Bostrom ${ }^{61}$ antecipa mudanças que ocorrerão neste século e alerta para emergência de uma superinteligência. A preocupação decorrente, não é apenas com o avanço da inteligência de máquina em curto prazo, mas com o progresso de máquinas autônomas letais, e uma ausência de reflexão ética sobre tais artefatos.

De outro lado, Bloch, no Post-Scriptum de sua obra Sujeito-Objeto, destaca que há uma tarefa da humanidade comum a todos, a saber, o dever de lutar em todas as partes para manter a existência em transição. Sabiamente o filósofo indaga: "por que tantas coisas claras permanecem sem serem vistas como se nunca existissem?"62 Teixeira em abordagem transcendente, preocupa-se em desvelar os segredos da espiritualidade e da técnica. Teixeira ${ }^{63}$ prescreve que o ser humano está diante do desafio permanente de prospectar "as coisas que estão por detrás das coisas" apropriando a visão utópica a um dinamismo dialético que é preciso ir na origem para recepcionar uma perspectiva de renovação.

Essa origem não é só o surgimento - Entshug -, mas o Ursprung - origem que se renova. A matéria que se dá a conhecer e trás na sua lógica a historicidade no movimento dialético da sua natureza. No conceito de Walter Benjamin: a origem é o alvo - "Ursprug ist der Ziel"; e conforme Bloch: a gênese é o fim ${ }^{64}$. Desvendar o mistério oculto na matéria seria uma das condições da

\footnotetext{
BLOCH, Ernst. Princípio Esperança. Tradução de Nélio Schneider. Rio de Janeiro: Editora UERJ/Contraponto, 2005. p. 295. v. 1. FOSSATTI, Nelson Costa. Utopias Técnicas - Ars Inveniendi além da Organicidade, 2016. p. 204-246. v. 1.

BOSTROM, Nick. Superinteligência - Caminhos, perigos e estratégias para um novo mundo. DarksSide Books, 2018. p. 471-473.

BLOCH. Sujeito-objeto: o pensamento de Hegel. Trad. Wenceslao Roces. México: Fondo de Cultura Económica, 1962. p. $473-481$.

TEIXEIRA, Evilázio. Espiritualidade e Técnica: As coisas que estão por detrás das coisas. Teocomunicação, Porto Alegre, v. 40, n. 3. p. 307-323, dez. 2010

64 FURTER, Pierre. Dialética da Esperança. Rio de Janeiro: Editora Paz e Terra, 1974.
} 
linguagem da unidade originária. O ser humano precisa decifrar a voz muda da natureza que revel seu fim a partir de sua gênese.

O filósofo de Tübigen ao ocupou-se da filosofia da natureza de Schelling, ${ }^{65}$ verifica a ausência da mediação imperativa (máxima universal kantiana) entre sujeito-objeto. Observou que a objetivação das utopias técnicas passaram a habitar um ethos estranho diante do antropocentrismo. O filósofo entende que a dialética da unidade originária contém em si a própria diferença que permite a autoformação da matéria e a decisão do uno em manifestar-se, produzindo a si mesmo ou manifestarse como natureza. Significa que há uma evidência desta dualidade (homem-natureza), demonstrando que a reconstituição da unidade originária não pode ser exorcizada pelo império da razão.

Na Metafísica dos Costumes, a ética parte da autonomia da razão, elegendo um universo antropocêntrico frente à natureza. Portanto, o ser humano reconhece sua liberdade segundo a capacidade da razão pura, de ser por si mesma prática e pela sujeição da máxima a qualificação como lei universal. Neste sentido a ética kantiana desconhece a autonomia da natureza uma vez que não é portadora de razão e, nesta condição responde por um déficit cosmológico.

Sabe-se que o cosmos, ao mover-se numa ontologia processual não euclidiana, sugere que a dualidade sujeito-matéria é portadora de liberdade, exigindo da ciência uma linguagem que ainda possa sondar possibilidades não antecipáveis que apresentam-se fora de controle da técnica. Não significa afirmar Aristóteles, que prescreve: "a liberdade existe só para coisas possiveis"; Ao contrário a liberdade também existe para coisas impossiveis latentes no âmbito da natureza. Nas utopias autárquicas, as possibilidades, não são antecipáveis, os eventos impossiveis (o que ainda-não-é) tendem a seu tempo ter sua possibilidade objetivada.

Nessas condições pode-se pensar que as utopias autárquicas concebidas no espaço evolutivo hegeliano unidirecional (com destino ao Uno) possuem um dinamismo plural. A existência desse dinamismo autárquico tende a ocorrer nos vários espaços e mundos possíveis. $O$ filósofo Luft sugere que esse dinamismo pode-se realizar em um espaço lógico, em um campo de infinitas possibilidades por estar relativamente indeterminadas nos vários mundos possiveis ${ }^{66}$. A imprevisibilidade dessas utopias ainda continua sendo o fenômeno capaz de explicar tanto os resultados benéficos esperados, assim como, a perversidade de suas contingências.

Atitudes autárquicas de dependência pressupõe que o sujeito transfira por vontade ou por desconhecimento as condições de autonomia a um outro ser, a uma máquina, um robô ou mesmo a algum algoritmo que venha a adquirir autonomia, uma IA com superinteligência. Bloch passa a ideia de que o ser humano não vai comportar-se como expectador ou mera plateia da natureza, com tendências à alienação; pelo contrário, o agente gerador de utopias, participa do dinamismo da matéria, tendo na esperança o impulso para transformação do mundo: de um ainda-não- ser que se propõe a ser.

As utopias se movimentam e despertam uma nova epifania, conduzindo o homo utopicus para um processo dialógico com o "ainda-não-ser na matéria". Contudo a linguagem ética poderia ser pensada através de um princípio categórico proposto por Bostrom, denominado Princípio do bem comum: "Uma superinteligência deverá ser desenvolvida apenas para benefício de toda a humanidade e a serviço de ideais éticos amplamente compartilhados por todos". ${ }^{67}$

Visto que as razões do antropocentrismo se consagraram em Descartes (pensamento - res cogitans); em Kant (autonomia da razão -capacidade de legislar) instrumentalizado pelo Organon, de Francis Bacon, que maximizou a superioridade do homem sobre a natureza. Pode-

65 BLOCH. Leipziger Vorlesungen zur Geschichte der Philosophie, p. 219-202.

66 LUFT, Eduardo. Ontologia deflacionária e ética objetiva: Em busca dos pressupostos ontológicos da teoria do reconhecimento. Revista Véritas, v. 55, n. 1 jan./abr., p. 82-120, 2010.

67 BOSTROM, Nick. Superinteligência - Caminhos, perigos e estratégias para um novo mundo. DarksSide Books, 2018. p. 457. Bostrom é diretor do Instituto para o Futuro da Humanidade; diretor do Strategic Al Research Centre; Professor da Faculdade de Filosofia \& Oxford Martin School - Universidade de Oxford. 
se indagar por que não mitigar o mandamento da razão de Kant que desconhece a natureza diante do antropocentrismo? Por que não dar exemplos de respeito ao ecossistema elegendo um imperativo cosmocêntrico, no interesse da paz, solidariedade entre os homens e desses em relação ao universo? Estes questionamentos sobre as tecnologias de rupturas ainda estão desafiado a ciência no alvorecer do século XXI.

O avanço das ciências e da instrumentalização da técnica, as utopias a autárquicas trilham um caminho e descrevem um rastro de incertezas. Entretanto permanecem indescritiveis os efeitos deletérios que a historia vai revelando no seu tempo.

Torna-se urgente identificar um imperativo ético cosmológico capaz de conduzir uma relação dialógica harmônica entre homem-natureza. Um dos primeiros passos seria pensar a reconciliação da unidade originária. No mundo da Ciência há um campo de possibilidades, cientistas, pesquisadores esperam que a humanidade possa viver uma grande ruptura, e tornem real a ideia de que uma nova singularidade possa resgatar esta reconciliação.

Contudo, o homo utopicus continua a ter pesadelos em seus sonhos acordados, a tecnologia instrumentaliza sempre mais a natureza que sente-se tencionada pela vontade soberana de seu hospedeiro mor. O mundo antropocêntrico na sua radicalidade se desenvolve inconsequente, quase sempre, produzindo singularidades que aprofundam as distâncias.

Esta aliança utópica entre natura naturans e natura naturata ainda está em nivel de possibilidades. O ser humano ao contemplar sua gênese e sua história parece concluir que a razão do regnus hominis, ainda em construção, ameaça a tendência que aponta para o resgate da unidade originária. Nessa perspectiva vive a esperança esclarecida (docta spes) que reivindica espaços no mundo vivido para eleger imperativos éticos universais que minimizem futuras contingências geradas pelas utopias autárquicas.

\section{Referências}

ALBORNOZ, Suzana. Ética e utopia: ensaio sobre Ernst Bloch. 2. ed. Porto Alegre: Movimento; Santa Cruz do Sul: Editora UNISC, 2006.

ALIGHIERI, Dante. A divina comédia. São Paulo: Abril Cultural, 1981

ARISTÓTELES. Metafísica. Trad. Leonel Vallandro. Porto Alegre: Editora Globo, 1969.

BACON, Francis. Novum Organum. São Paulo: Abril Cultural, 1973

BAVARESCO, Agemir. Princípio lógico universal e subsidiário como estruturante da natureza hegeliana. In: A noiva do espírito: natureza em Hegel. K. Utz et al. (org.). Porto Alegre: Edipucrs, 2010.

BLOCH, Ernst. Principio esperança. Tradução de Nélio Schneider. Rio de Janeiro: Editora UERJ/Contraponto, 2005. V. 1.

BLOCH, Ernst. Princípio esperança. Tradução de Nélio Schneider. Rio de Janeiro: Editora UERJ/Contraponto, 2005. v. 2.

BLOCH, Ernst. Princípio esperança. Tradução de Nélio Schneider. Rio de Janeiro: Editora UERJ/Contraponto, 2006. v. 3.

BLOCH, Ernst. Sujeito-Objeto: o pensamento de Hegel. Trad. Wenceslao Roces. México: Fundo de Cultura Económica, 1962

BLOCH, Ernst. Leipziger Vorlesungen zur Geschichte der Philosophie. In: Neuzeitliche Philosophie II: Deutscher Idealismus. Die Philosophie des 19. Frankfurt: Suhrkamp, 1991, v. 4

BOSTROM, Nick. Superinteligência - Caminhos, perigos e estratégias para um novo mundo. DarksSide Books, 2018. p.457

BRETON, Philippe. L'utopiede la communication. Paris: La Découverte.1995.

CARR, Nicholas. The shallows. New York: Norton Paperback, 2011.

CARSON, Rachel. Silent Spring. Boston: Houghton Mifflin,1962.

CASE, Amber. Calm Technology: Principles and Patterns for non-intrusive design. Gravenstein Highway North, Sebastopol, CA: 2016.

DAWKINS, Richard. O gene egoísta. Tradução de Rejane Rubino. São Paulo: Companhia das Letras, 2007.

FOSSATTI, Nelson Costa. Docta Spes e as Utopias técnicas: antinomia como tensão na esperança em Ernst Bloch. Porto Alegre: Editora Fi, 2016.

FOSSATTI, Nelson Costa. Utopias técnicas: Ars Inveniendi - Além da organicidade. In: SOUZA, Ricardo Timm de et al. (org.). Ernst Bloch: atualidade das utopias concretas. Porto Alegre, RS: Editora Fi, 2016. v.1.

FURTER, Pierre. Dialética da esperança. Rio de Janeiro: Paz e Terra, 1974 
GALIMBERTI, Umberto. Psiche e Techne: o homem na idade da técnica. São Paulo: Paulus, 2006.

GARDNER, James. O universo inteligente: inteligência artificial, extraterrestres e a mente emergente do cosmos. São Paulo: Cultrix, 2009

HEGEL, Georg Wilhelm Friedrich. Enciclopédia das Ciências Filosóficas. Tradução de Paulo Menezes. São Paulo: Loyola, 1995.

KANT, Immanuel. Fundamentação da metafísica dos costumes. Lisboa: Edições 70, 2008.

KANT, Immanuel. A metafísica dos costumes. Trad. Edson Bini. São Paulo: EDIPRO, 2003.

KELLY, Kevin. The Inevitable Understanding the 12 Technological Forces that will shape our future New York: Viking, 2016

KURZWEIL, Ray. The Singularity Is Near: When Humans Transcend Biology. Nova York: Viking, 2005

KURZWEIL, Ray. A era das máquinas espirituais Trad. Fabio Fernandes. São Paulo: Aleph, 2007.

LIBÂNIO, João Batista. Utopia e esperança cristã. São Paulo: Loyola, 1989.

LIN, Patrick et al. Robot Ethics: The Ethical and Social Implications of Robotics. Cambridge: MIT Press, 2012

LUFT, Eduardo. Ontologia deflacionária e ética objetiva: em busca dos pressupostos ontológicos da teoria do reconhecimento. Revista Véritas, v. 55, n. 1, p. 82-120, jan. /abr. 2010. https://doi. org/10.15448/1984-6746.2010.1.7324

McCORDUCK, Pamela. Machines who Think: A personal Inquiry into The History and Prospects of Artificial Intelligence. Massachusetts: AK Peter Ltd, 2004. https://doi.org/10.1201/9780429258985

MÜNSTER, Arno. Filosofia da práxis e utopia concreta. São Paulo: Edusp, 1993.

PEARSON, lan. You Tomorrow: The Future of Humanity, Gender, Everyday Life, and the Things around you. New York: Business, 2013.

PETITFILS, Jean-Christian. Os socialismos utópicos São Paulo: Círculo do Livro, 1977.

ROSSATTO, Noeli Dutra. Joaquim de Fiori: Trindade e Nova Era. Porto Alegre: EDIPUCRS, 2004

RÜDIGER, Francisco. Martin Heidgger e a questão da técnica: prospectos acerca do futuro do homem. Porto Alegre: Sulina, 2006.

SCHELLING, Friedrich Wilhelm Joseph Von. Ideias para uma filosofia da natureza. Lisboa: FCSH da Universidade Nova Lisboa: Imprensa Nacional Casa da Moeda, 2001.

SCHWAB, Klaus. The Fourth Industrial Revolution New York: Crown Business, 2016

SCHWARTZ, Sandra. A recepção da ética epicurista na utopia de Thomas Morus. Trad. Julia Brandão. Hildesheim: Georg Olms Verlag, 2003.
SOUZA, Draiton Gonzaga de. O ateísmo antropológico de Ludwig Feuerbach. Porto Alegre: EDIPUCRS, 1993

SOUZA, Ricardo Timm de. Ética como fundamento: uma introdução à ética contemporânea. São Leopoldo: Nova Harmonia, 2004

STEIN, Ernildo. Errar e pensar: um ajuste com Heidgger. ljui: Ed. Unijui, 2011.

TEIXEIRA, Evilázio. Espiritualidade e Técnica: As coisas que estão por detrás das coisas. Teocomunicação, Porto Alegre, v. 40, n. 3. p. 307-323, dez. 2010

TEIXEIRA, João de Fernandes. Inteligência artificial. São Paulo: Paulus, 2009.

TRIPLES, Frank; BARROW, John. The Anthropic Cosmological Principle. New York: Oxford-University Press, 1986.

TURKLE, Sherry. Alone together: why we expect more from technology and less from each other. New York: Published by Basic Books, 2011.

VÁZQUEZ. Adolfo Sánchez. Ética. Trad. João Dell'Anna. Rio de Janeiro: Civilização Brasileira, 2017.

VINGE, Vernor. The Coming Technological Singularity: How to Survive in the Post-Human Era. In: Vision 21 - Interdisciplinary Science and Engineering in the Era of Cyberspace. Ohio: NASA, 1993

\section{Nelson Costa Fossatti}

Doutor em Filosofia. Doutor em Comunicação Social. Mestre em Filosofia. Graduado em Engenharia Eletrônica/Telecomunicações. Pós-graduado em Redes de Comunicação de Dados e Serviços Telemáticos pela Pontificia Universidade Católica (PUCRS) em Porto Alegre, RS, Brasil. Mestre em Administração Universidade Federal do Rio Grande do Sul (UFRGS) em Porto Alegre, RS, Brasil. Professor titular na PUCRS.

\section{Endereço para correspondência}

Nelson Costa Fossatti

Pontifícia Universidade Católica do Rio Grande do Sul Av. Ipiranga, 6.681, Prédio 8, sala 403

Partenon 97010-082

Porto Alegre, RS, Brasil. 